\title{
Effect of Application Rhizobakter and Fungi Arbuscular Mycorhiza (Fma) on Growth and Results of Potato (Solanum tuberosum L.)
}

\author{
Weni Veriani; Prof. Dr. Ir. Warnita, MP; Dr. Ir. Indra Dwipa, MS; Dr. Ir. Zul \\ Irfan, MS
}

Department of Agriculture, Andalas University, Padang, Indonesia

\begin{abstract}
Indonesia national potato production is still relatively low compared with other countries. National potato production in 2017 range from 1,164,738 tonnes with an average per hectare production of western Sumatra 15.4 and 40398 tonnes with an average of 19.37 tonnes per hectare (CBS, 2018). While the production of other countries such as: Australia 39.69 tonnes / ha, with 47.15 tonnes / ha, Japan 30.65 tonnes / ha and Laos 30.04 tonnes / ha. The low productivity of potato in Indonesia can be caused by several factors, such as the limited avaiNARility of nutrients, poor quality seeds, post-harvest handling of seed and farming systems that are less good. One important factor that greatly affects the growth and yield of potato crop is limited nutrients provided one of them is' phosphate. Phosphate is an essential nutrient that is needed for the plants in regulating physiological processes of plants. So to improve the growth and yield of potatoes should be given rhizobakteri and arbuscular mycorrhizal fungi (AMF). Rhizobakter type used in this research iswithout rhizobakteri, RZ1.L2.4, RZ1.L2.1, RZ2.L2.1 while the FMA dose is $5 \mathrm{~g}, 10 \mathrm{~g}$ and $15 \mathrm{~g}$. The best treatment for the growth and yield of potato crop is rhizobakteri RZ2.L2.1 with a dose of $5 \mathrm{~g}$ FMA because it can increase net assimilation rate and leaf area index
\end{abstract}

Keywords-potatoes, rhizobakteri, arbuscular mycorrhizal fungi

\section{INTRODUCTION}

Potatoes along with corn, sorghum and rice are included in the five major world commodities as a staple food. Potatoes are horticultural commodities which have multifunctional, both as a source of carbohydrates and raw materials from a variety of other foods, including vegetables and snacks that can improve the nutritional status of the community. Potatoes discount high carbohydrate content which causes potato tuber known as a food ingredient that may replace other carbohydrateproducing foodstuffs such as rice, wheat and corn. This plant is a source of income and employment are high enough to contribute to the economic development of an area because it has been intensively cultivated by farmers (1).

So to improve the growth and yield of potatoes need to look for microorganisms that could help the release of $\mathrm{P}$ so that it becomes avaiNARle to plants. One of them using rhizobakteri. Rhizobakteri role as Plant Gowth Promoting Rhizobacteria (PGPR). The use of naturally Rhizobakteri associated with plant roots and have the ability to improve plant growth, as biological agents that stimulate plant growth and increase crop yields.
Rhizobakteri utilization is predicted to be an interesting study that continues to grow in the field of agriculture in the future (2). In addition to providing rizobakteri, to stimulate growth can also be used mycorrhizae. Mycorrhizal root system is a structure formed as a manifestation of their symbiotic mutualism between fungi (myces) and roots (rhiza) higher plants.

\section{MATERIALS AND METHODS}

This research has been conducted in experimental Land BPTP West Sumatra in Sukarami and preparation of is olates Rizobakteri conducted at the NARoratory of Microbiology, Faculty of Agriculture, University of Andalas Padang. Materials used are seed potatoes, isolates Rhizobakteri, FMA Multispora, water, paper NARels, plastic samples, envelopes, manure, lime, fertilizers NPK,

The experiment was arranged according to the design of $4 \times 3$ with two factors in a randomized block design (RBD) with three replications. The treatments were kind Rizobakteri (R) and the concentration of Mycorrhizal Fungi Fungi (M). Type Rizobakteri (R) provided consisted of four types: 
(R0) without Rhizobakteri

(R1) RZ1.L2.4

(R2) RZ1.L2.1

(R3) RZ2.L2.1

Dose Mycorrhiza Fungi Fungi (M) Multispora namely:

(M1) FMA dose of $5 \mathrm{~g} /$ plant

(M2) FMA dose of $10 \mathrm{~g} /$ plant

(M3) FMA dose of $15 \mathrm{~g} /$ plant

The data were analyzed by analysis of variance by $\mathrm{F}$ test, if the F-treatment count is greater than F-table then conducted a further test analyzes Duncan Multiple Range Test at 5 .

\section{RESULTS AND DISCUSSION}

\section{Net Assimilation Rate (NAR)}

Table 1 shows that treatment without rhizobakteri and rhizobakteri RZ2.L2.1 with a dose of $5 \mathrm{~g}$ FMA have significantly different NAR with FMA dose of $10 \mathrm{~g}$ and $15 \mathrm{~g}$ and $10 \mathrm{~g}$ no significant with $15 \mathrm{~g}$. Rhizobakteri RZ1.L2.4 with a dose of $15 \mathrm{~g}$ FMA have significantly different NAR with $5 \mathrm{~g}$ and $10 \mathrm{~g}$, whereas no significant both. While rhizobakteri RZ1.L2.1 with a dose of $10 \mathrm{~g}$ FMA have significantly different NAR with a dose of $5 \mathrm{~g}$ and $15 \mathrm{~g}$. The best treatment on without rhizobakteri obtained with a dose of $5 \mathrm{~g}$ FMA, FMA rhizobakteri RZ1.L2.4 with a dose of $15 \mathrm{~g}$ and rhizobakteri RZ2.L2.1 with FMA dose of $5 \mathrm{~g}$.

Table 1. Effect Rhizobakteri and Mycorrhizal Fungi Fungi against assimilation rate Net average Chips at Age $9 \mathrm{MST}$

\begin{tabular}{lccc}
\hline Isolates type & \multicolumn{4}{c}{ dose FMA } \\
\cline { 2 - 4 } Rhizobakteri & $5 \mathrm{~g}$ & $10 \mathrm{~g}$ & $15 \mathrm{~g}$ \\
\hline \multicolumn{4}{c}{$\ldots . \mathrm{mg} / \mathrm{cm} 2 /$ week $\ldots}$. \\
\hline without & $0.00115 \mathrm{a}$ & $0.00018 \mathrm{~b}$ & $0.00017 \mathrm{~b}$ \\
Rhizobakteri & $\mathrm{A}$ & $\mathrm{BC}$ & $\mathrm{AB}$ \\
& $0.00015 \mathrm{~b}$ & $0.00014 \mathrm{~b}$ & $0.00016 \mathrm{a}$ \\
RZ1.L2.4 & $\mathrm{C}$ & $\mathrm{C}$ & $\mathrm{AB}$ \\
& $0.0002 \mathrm{~b}$ & $0.0003 \mathrm{a}$ & $0.0001 \mathrm{~b}$ \\
RZ1.L2.1 & $\mathrm{C}$ & $\mathrm{A}$ & $\mathrm{B}$ \\
& $0.0009 \mathrm{a}$ & $0.0004 \mathrm{~b}$ & $0.0003 \mathrm{~b}$ \\
RZ2.L2.1 & $\mathrm{B}$ & $\mathrm{A}$ & $\mathrm{A}$ \\
\hline KK = 5:01\% & & &
\end{tabular}

The figures followed the same small letters on the same line and the same big letters in the same column according DNMRT no significant level of $5 \%$.

FMA dose of $5 \mathrm{~g}$ with no NAR rhizobakteri have significantly different to other treatments, a dose of $5 \mathrm{~g}$ with rhizobakteri FMA RZ2.L2.1 also significantly different with rhizobakteri RZ1.L2.4 and rhizobakteri RZ1.L2.1. NAR at FMA dose of $10 \mathrm{~g}$ with no significant RZ2.L2.1 rhizobakteri with rhizobakteri RZ1.L2.1 but significantly different from other treatments. FMA dose of $15 \mathrm{~g}$ with rhizobakteri RZ2.L2.1 have different NAR unreal with rhizobakteri RZ1.L2.4 and without rhizobakteri but significantly different with rhizobakteri RZ1.L2.1. The best treatment at a dose of $5 \mathrm{~g}$ obtained without rhizobakteri, FMA dose of $10 \mathrm{~g}$ with rhizobakteri RZ2.L2.1 and RZ1.L2.1.

NAR is basically an average size of leaf photosynthesis efficiency in a community of cultivated plants. Highest NAR obtained when the plants are still small and most of the leaves are still exposed to direct sunlight. Increasing age of the plant the NAR values will also increase and the leaves are protected more cause impairment NAR. Plants that have a high LAI highest young leaves have a chance to absorb the most sunlight, have the highest $\mathrm{CO} 2$ assimilation rate and mentranslokasikan largely the result of assimilation into other parts of the plants (3).

The statement shows that the older the plant, the lower the value of NAR. Besides plants having LAI values that are too high will reduce niali NAR plant. NAR will also affect the translocation of food reserves originating from metabolic processes.

\section{Leaf Area Index (LAI)}

Based on Table 2 treatment without Rhizobakteri at a dose of $5 \mathrm{~g}$ FMA significantly different at 10 and $10 \mathrm{~g} 15$ $\mathrm{g}$ but not significant at a dose of $15 \mathrm{~g}$ on average LAI potato plants. Giving Rhizobakteri RZ1.L2.4 with a dose of $10 \mathrm{~g}$ FMA significantly different from the dose of $5 \mathrm{~g}$ and 15 g. Giving Rhizobakteri RZ1.L2.1 with FMA dose of $10 \mathrm{~g}$ and $15 \mathrm{~g}$ doses significantly different with $5 \mathrm{~g}$. While the provision of Rhizobakteri RZ2.L2.1 with a dose of $5 \mathrm{~g}$ FMA significantly different from the dose of $10 \mathrm{~g}$ and $15 \mathrm{~g}$.

Table 2. Effect Rhizobakteri and fungi Mycorrhizal Fungi on Leaf Area Index Average Average Chips At Age 9 MST

\begin{tabular}{lccc}
\hline Isolates type & \multicolumn{3}{c}{ dose FMA } \\
Rhizobakteri & $5 \mathrm{~g}$ & $10 \mathrm{~g}$ & $15 \mathrm{~g}$ \\
\cline { 2 - 4 } & $0.03093 \mathrm{a}$ & $0.00808 \mathrm{~b}$ & $0.01061 \mathrm{~b}$ \\
\hline without & $\mathrm{B}$ & $\mathrm{D}$ & $\mathrm{C}$ \\
Rhizobakteri & $0.01060 \mathrm{~b}$ & $0.01637 \mathrm{a}$ & $0.00523 \mathrm{c}$ \\
& $\mathrm{C}$ & $\mathrm{C}$ & $\mathrm{D}$ \\
RZ1.L2.4 & $0.0128 \mathrm{~b}$ & $0.0315 \mathrm{a}$ & $0.0360 \mathrm{a}$ \\
& $\mathrm{C}$ & $\mathrm{A}$ & $\mathrm{A}$ \\
RZ1.L2.1 & $0.0465 \mathrm{a}$ & $0.0272 \mathrm{~b}$ & $0.0200 \mathrm{c}$ \\
& $\mathrm{A}$ & $\mathrm{B}$ & $\mathrm{B}$ \\
RZ2.L2.1 & \multicolumn{3}{c}{} \\
\hline KK $=5$. & \multicolumn{3}{c}{} \\
\hline
\end{tabular}


The figures followed the same small letters on the same line and the same big letters in the same column according DNMRT no significant level of $5 \%$.

Based on these explanations can be concluded that a dose FMA without rhizobakteri best in treatment is a dose of $5 \mathrm{~g}$, rhizobakteri RZ1.L2.4 is a dose of $10 \mathrm{~g}$, rhizobakteri RZ1.L2.1 is a dose of $10 \mathrm{~g}$ and $15 \mathrm{~g}$, while rhizobakteri RZ2.L2 .1 is a dose of $5 \mathrm{~g}$. FMA dose of $5 \mathrm{~g}$ with rhizobakteri RZ2.L2.1 significantly different with other treatments, without rhizobakteri also significantly different but the provision rhizobakteri RZ1.L2.4 and RZ1.L2.1 but giving no significant RZ1.L2.4 rhizobakteri with RZ1.L2.1. FMA dose of $10 \mathrm{~g}$ and $15 \mathrm{~g}$ with rhizobakteri RZ1.L2.1 significantly different with all treatments. FMA dose of $10 \mathrm{~g}$ and $15 \mathrm{~g}$ with rhizobakteri RZ2.L2.1 significantly different from the administration and without rhizobakteri RZ1.L2.1 rhizobakteri. The best treatment at a dose of $5 \mathrm{~g}$ FMA is to rhizobakteri RZ2.L2.1, FMA dose of $10 \mathrm{~g}$ and $15 \mathrm{~g}$ are with rhizobakteri RZ1.L2.1.

It shows every rhizobakteri have different responses to the FMA doses are given in influencing the value of LAI. Rhizobakteri Each type has its own characteristics, it may be rhizobakteri RZ2.L2.1dengan FMA dose of $5 \mathrm{~g}$ has a higher ability to support the growth of plant leaves. Based on Table 6 it can be seen that the most number of leaves on RZ2.L2 rhizobakteri treatment is with a dose of $5 \mathrm{~g}$ FMA as well as with rhizobakter RZ1.L2.1 a dose of $10 \mathrm{~g}$ and $15 \mathrm{~g}$. If korelassi between factors associated with it can be seen that the number of leaves with LAI have a strong positive correlation, where the addition value of the number of leaves a little to be significantly mmeningkatkan LAI value.

These results are consistent with the statement which LAI is the ratio between leaf area and an area of land that is overgrown potato plants at any time. Sne of the factors that influence the value of LAI is the number of leaves of the plant. Leaves that have higher numbers with a size larger then the plant has a higher LAI value (3).

Increased LAI make a positive contribution to the growth of the plant, because the leaf is the main organ where photosynthesis. Therefore, the optimum number of leaves that allow the distribution of the light between the leaves evenly. Light distribution evenly between the leaves reduces the incidence of each shade between the leaf so that each leaf can work as it should LAI on most plants in the field is zero and for a few weeks and then can be below 1.0 further increase in LAI rapidly until it reaches the maximum can vary between species and the environment (4). Large leaf area is usually maintained until the close before maturity, unless the leaves are affected by plant pests and the environment (5).

\section{CONCLUSION}

The best treatment of this research is rhizobakteri RZ2.L2.1 with a dose of $5 \mathrm{~g}$ FMA because it can increase the value llaju net assimilation and leaf area index.

\section{REFERENCES}

[1] Hanan, Ridwan, MeriyantodanBerlian Ade Putra. 2015. ResponTanamanKentang (Solanumtuberosum L.) akibat Pemberian Mikroorganisme Lokal (MOL) Bonggol Pisang di Dataran Medium. Universitas Tridinanti. Palembang.

[2] Sutariati, G.A.K dan A. Wahab. 2010. Isolasi dan Uji Kemampuan Rizobakteri Indigenous Sebagai Agensia Pengendali Hayati pada tanaman Cabai. Jurnal Hortikultura. 20(1): 86-95.

[3] Gardner, F.P., R.B. Peace dan R.L. Mitchell. 1991. Fisiologi Tanaman Budidaya Universitas Indonesia Press 428. Jakarta.

[4] Sitompul, S. M. dan Guritno, B. 1995. Analisis Pertumbuhan Tanaman. UGM Press: Yogjakarta.

[5] Fitter, AH dan Hay RKM. 1994. Fisiologi Lingkungan Tanaman. Universitas Press. Yogy akarta. 